\title{
PENGARUH KOMITMEN DAN IMPLEMENTASI TOTAL QUALITY MANAGEMENT (TQM) TERHADAP KINERJA MANAJERIAL DI KAWASAN INDUSTRI KARAWANG
}

\author{
Puji Isyanto \\ Universitas Buana Perjuangan Karawang \\ email : puji.isyanto@ubpkarawang.ac.id
}

\begin{abstract}
This study aims to find the influence of the manager's commitment and implementation of total quality management (TQM) to managerial performance in companies in the industrial area Karawang. This study uses a survey of 158 managers in the company-company industrial area of the city of Karawang. The data used in this study, consisting of primary data obtained through the results of questionnaires and secondary data which supports research that studies literature and journals. Testing hypotheses using path analysis. Based on the results of the study found that: (1). A significant difference between the manager's commitment to the Managerial Performance, (2) There is a significant relationship between Total Quality Management Implementation of the Managerial Performance and (3). A significant difference between commitment and implementation manager of the Total Quality Management Company Operation Manager Performance.
\end{abstract}

Keywords: commitments manager, implementation of TQM, and company operation manager performance

\section{Latar Belakang Penelitian}

Kebutuhan masyarakat yang semakin banyak mengakibatkan bidang usaha tumbuh dan berkembang pesat. Perkembangan bidang usaha yang pesat ini mengakibatkan persaingan semakin besar diantara perusahaan-perusahaan yang menyediakan kebutuhan masyarakat tersebut. Persaingan yang dihadapi oleh perusahaan - perusahaan bukan hanya dari perusahaan dalam negeri saja tetapi dari perusahaan luar negeri juga. Selain itu, perusahaan yang telah lama beroperasi untuk menyediakan kebutuhan masyarakat harus bersaing dengan perusahaanperusahaan yang baru beroperasi. Perusahaan-perusahaan harus mendapat keuntungan (profit) untuk dapat terus bersaing, beroperasi dan berkembang menjadi perusahaan yang lebih besar.

Setiap perusahaan dapat meningkatkan daya saing melalui kapabilitas yang dimiliki dalam organisasi. Kemampuan bersaing setiap perusahaan mengacu pada posisi relatif perusahaan tersebut dibandingkan dengan perusahaan lain dalam pasar lokal maupun global (Kuncoro, 2008:20). Keunggulan daya saing dapat diperoleh apabila setiap perusahaan memiliki kemampuan untuk menyajikan setiap proses dalam operasi bisnisnya secara lebih baik dalam menghasilkan barang dan jasa yang mempunyai kualitas tinggi dengan harga yang bersaing. Sehingga produk yang 
dihasilkan mampu bersaing baik dari sisi kualitas, harga, penyerahan produk, dan fleksibilitas dibandingkan pesaingnya di pasar (Heizer dan Render, 2004: 93-96).

Produk menjadi instrumen penting untuk mencapai kesuksesan dan kemakmuran pada suatu perusahaan. Perkembangan teknologi, peningkatan persaingan global, serta kebutuhan dan keinginan pasar mengharuskan perusahaan melakukan pengembangan produk yang terus-menerus. Hanya ada dua pilihan yaitu sukses dalam pengembangan produk sehingga menghasilkan produk yang unggul, atau gagal dalam pencapaian tujuan bisnisnya, karena produk yang dihasilkan tidak mampu bersaing di pasar. Kualitas juga merupakan hal yang paling mendasar dari kepuasan konsumen dan kesuksesan dalam bersaing. Kenyataannya kualitas merupakan hal yang seharusnya untuk semua ukuran perusahaan dan untuk tujuan mengembangkan praktek kualitas serta menunjukkan ke konsumen bahwa mereka mampu menemukan harapan akan kualitas yang semakin tinggi.

Setiap perusahaan perlu adanya pengukuran kinerja, pengukuran kinerja merupakan aktivitas yang paling penting bagi manajemen dalam mengelola organisasi perusahaan. Fakta menunjukan bahwa tanpa dilakukan suatu pengukuran terhadap kinerja, maka sulit untuk memperbaikinya. Oleh karena itu, meningkatkan kinerja organisasi memerlukan identifikasi terhadap variabel-variabel yang mempengaruhinya dan mengukurnya dengan akurat. Pengukuran kinerja sangat penting dilakukan bagi suatu organisasi, agar dapat tercapai kinerja bisnis yang optimal (Demirbag et al. 2006:57).

Kabupaten Karawang sebagai kawasan industri di Indonesia merupakan kawasan industri yang berkembang sangat pesat akhir-akhir ini. Jumlah industri di Karawang sebesar 9.582 unit sedangkan pada 2011 sebesar 9763 unit. Pada tahun 2013, jumlah industri di Karawang mencapai 9.920 unit dan terus menerus akan bertambah. Hal ini menunjukan bahwa Karawang mempunyai potensi untuk menjadi kawasan Industri yang besar. Dengan besarnya jumlah Industri di Karawang, maka diharapkan bahwa industri-industri di Karawang menggunakan sistem alat bantu TQM untuk meningkatkan kualitas produknya sehingga keuntungan yang didapat oleh industri di Karawang sangat besar.

Perusahaan tentu memiliki sosok seorang pemimpin dalam hal ini yaitu seorang manajer perusahaan, yang menjadi motivator bagi karyawan-karyawannya dan salah satu ujung tombak dari keberhasilan suatu organisasi adalah kepemimpinan yang akan ditunjukkan oleh adanya interaksi antara pimpinan puncak, manajer divisi dan karyawan. Interaksi ditunjukkan dengan kerjasama satu sama lain dalam menangani masalah organisasi. Para manajer divisi berperan penting mengkomunikasikan aktivitas organisasi yang akan dilaksanakan sesama manajer, demikian juga yang harus diteruskan kepada karyawannya. Komunikasi yang terjadi di antara para manajer maupun kepada bawahan sangat dipengaruhi oleh persepsi masing-masing manajer tersebut tentang informasi mengenai TQM yang diterima dari atasannya dan dari sesama manajer divisi. Tan dan Hunter (2002:42) mengemukakan persepsi ditinjau dari kognisi pemakai melalui pengenalan dan keahlian dalam sistem informasi memiliki hubungan dengan persepsi manajer, serta akan berdampak terhadap kinerja. Demikian juga semakin baik persepsi manajer melalui pengenalan dan keahlian total quality management akan berpengaruh terhadap kinerja manajer tersebut. Dengan demikian 33|Jurnal Manajemen \& Bisnis Kreatif 
kepemimpinan yang ditunjukkan melalui komitmen pimpinan puncak dan persepsi manajer divisi mengenai TQM perlu disinerjikan.

Komitmen dari seorang manajer perusahaan merupakan sesuatu yang sangat penting, karena dengan adanya komitmen manajer berupa keinginan untuk meningkatkan perusahaan hal ini akan berdampak pula dengan sikap loyalitas para karyawannya, seorang pemimpin atau manajer tidak menginginkan seluruh jajaran anggotanya tidak memiliki komitmen yang kuat terhadap organisasi / perusahaan mereka. Bahkan sampai sejauh ini banyak pimpinan organisasi yang berusaha menggiatkan peningkatan komitmen para karyawannya agar para karyawan memiliki rasa kepemilikan terhadap perusahaan, bila faktor ini sudah terbentuk para karyawan akan merasa terlibat dan semua idenya dipertimbangkan, maka muncul perasaan kalau mereka ikut berkontribusi terhadap pencapaian hasil apalagi ditambah dengan kepercayaan kalau hasil yang diperoleh organisasi akan kembali pada kesejahteraan mereka pula.

Berdasarkan pengamatan yang terjadi pada perusahaan-perusahaan di daerah industri Karawang, kinerja perusahaan yang rendah hal ini disebabkan oleh ketergantungannya terhadap sistem manajemen perusahaan yang gagal dalam penentuan sasaran - sasaran yang tepat, pengukuran kinerja, dan sistem reward yang dilakukan oleh pihak manajemen perusahaan dalam hal ini pihak manajer, karena itu penetapan implementasi penerapan TQM memerlukan perubahan mendasar infrastruktur organisasional, meliputi sistem alokasi wewenang pembuatan keputusan, sistem pengukuran kinerja, sistem reward dan hukuman (Dari pengamatan tersebut menunjukan bahwa tidak ada sistem manajemen secara universal yang selalu tepat untuk bisa diterapkan pada seluruh organisasi pada setiap keadaan, namun sistem manajemen tersebut tergantung juga pada faktor faktor kondisional yang ada dalam organisasi dan TQM yang merupakan suatu proses yang panjang dan berlangsung terus menerus, karena budaya organisasi merupakan salah satu faktor yang cukup sulit untuk dirubah. Keberhasilan penerapan TQM akan berdampak pada penurunan biaya akibat turunnya kerusakan atau kegagalan produk dan kemampuan menghindari pemborosan biaya yang tidak bernilai bagi pelanggan. Penurunan biaya tidak semata - mata hanya pengurangan biaya produksi, namun juga aktivitas berlebih, tanpa mengorbankan mutu produk yang dihasilkan. Peningkatan mutu diyakini sebagai cara yang sangat efektif dilakukan seorang manajer untuk meningkatkan pangsa pasar, dan perusahaan yang memiliki keunggulan biaya serta pangsa pasar yang luas, maka manajer akan menuai prestasi yang tinggi. (Mardiyah dan Listianingsih, 2005:566).

Berdasarkan fenomena-fenomena masalah pada masing-masing variabel diatas hasil survey awal pada 15 orang responden, perlu adanya solusi permasalah awal melalui sebuah kajian, Brah and Lim (2006:15-11) mengatakan bahwa kinerja perusahaan dapat diukur dalam dua dimensi kinerja yaitu: kinerja operasional dan kinerja organisasi. Kinerja operasional mencerminkan kinerja operasi internal perusahaan dalam hal biaya dan pengurangan pemborosan, meningkatkan kualitas produk, pengembangan produk baru, memperbaiki kinerja pengiriman, dan peningkatan produktivitas. Indikator dan variabel tersebut dianggap sebagai faktor utama karena mereka mengikuti langsung dari tindakan yang diambil dalam kegiatan operasi perusahaan. Sedangkan kinerja organisasi diukur dengan ukuran 34|Jurnal Manajemen \& Bisnis Kreatif 
finansial seperti pertumbuhan pendapatan, laba bersih, rasio laba dengan pendapatan dan laba atas asset, dan non-ukuran finansial seperti investasi dalam R\&D, dan kapasitas perusahaan untuk mengembangkan profil kompetitif. Untuk mencapai keberhasilan TQM pula dibutuhkan praktek TQM yang nyata dengan kualitas data dan pelaporan yang dihasilkan manajemen perusahaan, peran manajemen perusahaan, hubungan dengan karyawannya, manajemen sebagai fungsi pemasok, dan pelatihan kebijakan mutu dan proses, dengan adanya hal tersebut perlunya dilakukan adanya kajian mengenai bagaimana pengaruh Komitmen dan Implementasi Total Quality Management (TQM) terhadap kinerja manajerial.

Berdasarkan latar belakang dan judul penelitian diatas, maka perumusan masalah penelitian ini adalah bagaimana Komitmen manajer, implementasi TQM, kinerja manajerial dan pengaruhnya di perusahaan-perusahaan di kawasan industri Karawang. Sesuai dengan rumusan masalah tujuan penelitian ini untuk mengkaji bagaimana komitmen manajer, implementasi TQM, kinerja manajerial dan pengaruhnya di perusahaan-perusahaan di kawasan industri Karawang.

\section{Tinjauan Pustaka Komitmen}

Menurut Panggabean (2004:132) komitmen adalah kuatnya pengenalan dan keterlibatan seseorang dalam suatu organisasi tertentu. Dilain pihak komitmen sebagai kecenderungan untuk terikat dalam garis kegiatan yang konsisten karena menganggap adanya biaya pelaksanaan kegiatan yang lain (berhenti bekerja). Komitmen karyawan mengandung pengertian sebagai suatu hal yang lebih baik dari sekedar kesetiaan yang pasif melainkan menyiratkan hubungan pegawai dengan perusahaan secara aktif. Karena pegawai yang menunjukkan komitmen tinggi memiliki keinginan untuk memberikan tenaga dan tanggung jawab yang lebih dalam menyokong kesejahteraan dan keberhasilan organisasinya.

Menurut Sunarto (2005:25), komitmen adalah kecintaan dan kesetiaan, terdiri dari :

a. Penyatuan dengan tujuan dan nilai-nilai perusahaan

b. Keinginan untuk tetap berada dalam organisasi

c. Kesediaan untuk bekerja keras atas nama organisasi.

Komitmen manajer atau pimpinan menurut Munandar (2004:75) terbagi atas tiga komponen,yaitu :

1. Komponen afektif berkaitan dengan emosional, identifikasi, dan keterlibatan pegawai di dalam suatu organisasi. Pegawai dengan afektif tinggi masih bergabung dengan organisasi karena keinginan untuk tetap menjadi anggota organisasi.

2. Komponen normatif merupakan perasaan pegawai tentang kewajiban yang harus diberikan kepada organisasi. Komponen normatif berkembang sebagai hasil dari pengalaman sosialisasi, tergantung dari sejauh apa perasaan kewajiban yang dimiliki pegawai. Komponen normatif menimbulkan perasaan kewajiban kepada pegawai untuk memberikan balasan atas apa yang pernah diterimanya dari organisasi. 
3. Komponen continuance berarti komponen yang berdasarkan persepsi pegawai tentang kerugian yang akan dihadapinya jika meninggalkan organisasi. Pegawai dengan dasar organisasi tersebut disebabkan karena pegawai tersebut membutuhkan organisasi. Pegawai yang memiliki komitmen organisasi dengan dasar afektif memiliki tingkah laku yang berbeda dengan pegawai dengan dasar continuance. Pegawai yang ingin menjadi anggota akan memiliki keinginan untuk berusaha yang sesuai dengan tujuan organisasi.

Sedangkan Menurut Panggabean (2004:132) ada beberapa jenis komitmen organisasi, diantaranya :

1. Affective Commitment

Affective Commitment adalah tingkat seberapa jauh seorang karyawan secara lebih terikat, mengenal, dan terlibat dalam organisasi. Karyawan dengan Affective Commitment yang tinggi tentang tinggal dengan organisasi karena mereka mau. Orang-orang ini mengenal organisasi dan terikat untuk tetap menjadi anggota organisasi untuk mencapai tujuan organisasi.

2. Normative Comitment

Menunjuk kepada tingkat seberapa jauh seseorang secara psychological terikat untuk menjadi karyawan dari sebuah organisasi yang didasarkan kepada perasaan seperti kesetiaan, affeksi, kehangatan, pemilikan, kebanggaan, kesenangan, kebahagiaan, dll.

Komitmen seorang manajer pada organisasi tidak terjadi begitu saja terbentuk, tetapi melalui proses yang cukup panjang dan bertahap. Steers (2008:110) menyatakan ada tiga faktor yang mempengaruhi komitmen seorang manajer di perusahaan. Berikut ini adalah ketiga faktor tersebut.

1. Ciri pribadi pekerja seperti termasuk masa jabatannya dalam organisasi, dan variasi kebutuhan dan keinginan yang berbeda dari tiap karyawan.

2. Ciri pekerjaan, seperti identitas tugas dan kesempatan berinteraksi dengan rekan sekerja.

3. Pengalaman kerja, seperti keterandalan organisasi di masa lampau dan cara pekerja-pekerja lain mengutarakan dan membicarakan perasaannya tentang organisasi

Sedangkan David (2008:163) mengemukakan ada empat faktor yang mempengaruhi komitmen organisasi.Berikut ini adalah keempat faktor tersebut.

1. Faktor personal, misalnya usia, jenis kelamin, tingkat pendidikan, pengalaman kerja dan kepribadian.

2. Karakteristik pekerjaan, misalnya lingkup jabatan, tantangan dalam pekerjaan, konflik peran, tingkat kesulitan dalam pekerjaan.

3. Karakteristik struktur, misalnya besar kecilnya organisasi, bentuk organisasi, kehadiran serikat pekerjan, dan tingkat pengendalian yang dilakukan organisasi terhadap karyawan.

4. Pengalaman kerja. 
E-ISSN: 2580-5428

Pengalaman kerja seorang manajer sangat berpengaruh terhadap tingkat komitmen manajer pada organisasi perusahaan. Manajer yang baru beberapa tahun menjabat dan manajer yang sudah puluhan tahun menjabat dalam organisasi tentu memiliki tingkat komitmen yang berlainan.

\section{Total Quality Management (TQM)}

Total Quality Management (TQM) adalah sebuah visi dimana perusahaan dapat mencapai rencana panjang dengan menerapkan sebuah kualitas rencana yang secara perlahan-lahan memimpin perusahaan tersebut menuju kepada pencapaian visi yang telah ditetapkan. Berikut ini adalah hirakhi sebuah pengertian kualitas yang merupakan bagian dari TQM:

a. Quality - untuk melanjutkan harapan dari pelanggan

b. Total Quality - Untuk mencapai quality dengan harga yang rendah

c. Total Quality Management - untuk mencapai total quality melalui partisipasi semua pegawai

Pada saat pasar dalam negeri dan pasar luar negeri sedang mengalami persaingan besar, kebanyakan perusahaan menyadari bahwa TQM sangat dibutuhkan untuk bertahan dalam persaingan. Sekarang, konsumen dapat mengambil dan memilih produk-produk yang saling bersaing dan konsumen memilih produk yang memiliki kualitas tertinggi sebagai pengganti uang yang telah mereka keluarkan untuk membeli barang tersebut.

Konsep dari TQM merupakan pengembangan pemikiran dari Total Quality Control (TQC), sebuah konsep yang pertama sekali diperkenalkan oleh A.V. Feigenbaum pada tahun 1960 dimana hal ini telah dipikirkan di dunia engineering tetapi pemikiran ini tidak pernah diterima oleh perusahaan barat. TQC kemudian diadopsi oleh jepang dimana pertama kali dilaksanakan pada tahun 1962. Di Jepang, TQC sangat berkembang pesat dan dinamakan dengan Company Wide Quality Control (CWQC). CWQC tentu sama dengan TQM yang dilaksanakan oleh perusahaan barat.

Dibuku Total Quality Control oleh Feigenbaum (1960, p.11) dicantumkan bahwa TQC merupakan sistem yang efektif untuk integrasi semua keinginan di bidang quality untuk menghasilkan produksi barang dan jasa dengan harga yang murah sesuai dengan keinginan konsumen. Pengertian ini mengandung akar permasalahan. Alasan mengapa TQC tidak sukses di perusahaan barat karena perusahaan barat salah mengambil persepsi tentang TQC bahwa TQC bisa dilaksanakan hanya oleh quality department. Hasilnya, manajemen gagal menyadari bahwa pentingnya unsur-unsur TQC adalah untuk membuat komitmen dalam pengembangan kualitas. Sistem yang efektif adalah suatu hal yang penting tetapi bukan berarti merupakan kondisi yang memadai untuk TQC.

Total Quality Management merupakan suatu konsep yang berupaya melaksanakan sistem manajemen kualitas kelas dunia. Untuk itu diperlukan perusahaan besar dalam budaya dan sistem nilai suatu organisasi. Menurut Hensler dan Brunell dalam Nasution (2010:30), ada empat prinsip utama dalam total quality management. Keempat prinsip tersebut adalah:

1. Kepuasan pelanggan 
Kebutuhan pelanggan internal dan pelanggan eksternal harus selalu dipuaskan, baik dari segi produk, pelayanan, harga, keamanan dan ketepatan waktu. Kepuasan pelanggan akan terjadi apabila pelayanan yang diberikan sesuai dengan apa yang diharapkan pelanggan, namun yang sering terjadi ialah kesenjangan di antara keduanya, sehingga pelanggan sulit untuk merasa puas. Suatu produk yang dihasilkan baru dapat dikatakan berkualitas apabila sesuai dengan keinginan pelanggan, dengan demikian produk harus diproduksi dan pelayanan harus diberikan sesuai dengan kebutuhan dan keinginan pelanggan. Dengan berorientasi pada kepuasan pelanggan, perusahaan akan meningkatkan kinerjanya dan meningkatkan kualitas produk dan pelayanannya secara terusmenerus dan cepat tanggap terhadap keinginan pelanggan yang selalu berubah.

2. Respek terhadap semua orang

Setiap orang dalam perusahaan harus dipandang sebagai sumber daya yang paling bernilai karena memiliki talenta tersendiri yang unik, karena itu harus diperlakukan dengan baik dan diberi kesempatan untuk terlihat dan berpartisipasi dalam tim pengambil keputusan. Terkadang perusahaan hanya melakukan perbaikan dan pemeliharaan terhadap produk saja dan melupakan keberadaan karyawan sebagai kunci utama kesuksesan. Membina hubungan baik dalam perusahaan akan membuat karyawan merasa dipercaya dan diandalkan, sehingga memacu mereka untuk menciptakan ide dan kreativitas baru yang nantinya dapat meningkatkan produktivitas dan dapat meningkatkan kualitas pelayanan yang dilakukan terhadap masyarakat dengan tetap menanamkan sikap saling menghormati.

3. Manajemen berdasarkan fakta

Pengambilan setiap keputusan dalam perusahaan harus berdasarkan fakta yang terjadi di lapangan, yang telah dipastikan kebenarannya, bukan hanya berdasarkan perasaan dan pengalaman semata. Perubahan selalu terjadi secara terus-menerus, maka perusahaan pun harus terus mengikuti perkembangan jaman. Dengan melihat pada fakta yang telah dikumpulkan dan diolah menjadi data, maka dapat diketahui kondisi perusahaan yang akurat, sehingga manajemen dapat memprediksi hasil dari setiap keputusan dan tindakan yang dilakukan dengan tepat. Dengan data itu pula, perusahaan dapat mengetahui bagian-bagian yang perlu perbaikan, sehingga perbaikan dapat dilakukan pada bagian yang paling memerlukan terlebih dahulu, karena perbaikan tidak dapat dilakukan pada semua aspek pada saat yang bersamaan dikarenakan keterbatasan sumber daya. Perbaikan-perbaikan yang dilakukan perusahaan tersebut pada akhirnya akan mampu meningkatkan kualitas produk dan pelayanan yang diberikan kepada masyarakat.

4. Perbaikan berkesinambungan

Setiap perusahaan perlu melakukan perbaikan berkesinambungan untuk mencapai kesuksesan. Dalam perbaikan berkesinambungan, produk dikatakan gagal apabila menyimpang dari harapan pelanggan. Untuk melakukan perbaikan berkesinambungan tidak hanya diperlukan peningkatan sumber daya, tetapi peningkatan sistem. Dalam memecahkan masalah, perusahaan harus mencari sumber / penyebab masalah dan solusi masalah sekaligus, tidak boleh hanya menekankan pada salah satunya saja. Hal yang paling penting dalam perbaikan 
E-ISSN: 2580-5428

berkesinambungan adalah komunikasi, agar masing-masing bagian mengetahui job desk-nya dan saling melaporkan kemajuan maupun kemunduran yang terjadi, serta tetap memantau perubahan. Dengan dilaksanakannya perbaikan berkesinambungan, maka akan berdampak terhadap peningkatan kualitas produk dan juga pelayanan perusahaan

Ada sepuluh karakteristik TQM yang dikembangkan oleh Goetsch dan David dalam Nasution (2005:22-24) yaitu :

\section{Fokus Pada Pelanggan}

Pelanggan merupakan sosok yang harus dilayani. Dimana perhatian difokuskan pada kebutuhan dan harapan para pelanggan. Untuk setiap organisasi yang menerapkan TQM harus benar-benar mengetahui, mengidentifikasi dan menganalisis kebutuhan dan harapan pelanggannya agar bisa memuaskannya. Dimana produk/jasa yang dibuat atau diberikan haruslah sesuai dengan keinginan para pelanggan.

2. Obsesi terhadap Kualitas

Dalam organisasi yang menerapkan TQM, obsesi utama suatu perusahaan yaitu meningkatkan kualitas baik itu kualitas produk/jasa, tenaga kerja, proses dan lingkungan kerja dimana kualitas merupakan faktor penting untuk meningkatkan kinerja perusahaan dan karyawan serta dalam menarik konsumen/pelanggan.

3. Pendekatan Ilmiah

Pendekatan ini sangat diperlukan dalam penerapan TQM, terutama untuk mendesain pekerjaan dan dalam proses pengambilan keputusan dan pemecahan masalah yang berkaitan dengan pekerjaan yang didesain tersebut. Dengan demikian, data diperlukan dan dipergunakan dalam menyusun patok duga (benchmark), memantau prestasi, dan melaksanakan perbaikan.

4. Komitmen Jangka Panjang

TQM merupakan suatu paradigma baru dalam melaksanakan bisnis. Untuk itu, dibutuhkan budaya perusahaan yang baru pula. Oleh karena itu, komitmen jangka panjang sangat penting guna mengadakan perubahan budaya agar penerapan TQM dapat berjalan dengan sukses.

5. Kerjasama Tim (Teamwork)

Dalam organisasi yang dikelola secara tradisional seringkali diciptakan persaingan antar departemen yang ada dalam organisasi tersebut agar daya saingnya terdongkrak. Sementara itu, dalam organisasi yang menerapkan TQM, kerjasama tim, kemitraan, dan hubungan dijalin dan dibina, baik antar karyawan perusahaan maupun dengan pemasok, lembaga-lembaga pemerintah, dan masyarakat sekitarnya.

6. Perbaikan Sistem Secara Berkesinambungan

Setiap produk dan atau jasa dihasilkan dengan memanfaatkan proses - proses tertentu di dalam suatu sistem / lingkungan. Oleh karena itu, sistem yang ada perlu diperbaiki secara terus-menerus agar kualitas yang dihasilkannya dapat makin meningkat.

7. Pendidikan dan Pelatihan

Dewasa ini masih terdapat perusahaan yang menutup mata terhadap pentingnya pendidikan dan pelatihan karyawan. Kondisi seperti itu menyebabkan 
perusahaan yang bersangkutan tidak berkembang dan sulit bersaing dengan perusahaan lainnya, apalagi dalam era persaingan global. Sedangkan dalam organisasi yang menerapkan TQM, pendidikan dan pelatihan merupakan faktor yang fundamental. Setiap orang diharapkan dan didorong untuk terus belajar. Dengan belajar, setiap orang dalam perusahaan dapat meningkatkan keterampilan teknis dan keahlian profesionalnya.

8. Kebebasan yang Terkendali

Dalam TQM, keterlibatan dan pemberdayaan karyawan dalam pengambilan keputusan dan pemecahan masalah merupakan unsur yang sangat penting. Hal ini dikarenakan unsur tersebut dapat meningkatkan 'rasa memiliki' dan tanggung jawab karyawan terhadap keputusan yang telah dibuat. Meskipun demikian, kebebasan yang timbul karena keterlibatan dan pemberdayaan tersebut merupakan hasil dari pengendalian yang terencana dan terlaksana dengan baik.

9. Kesatuan Tujuan

Agar TQM dapat diterapkan dengan baik, maka perusahaan harus memiliki kesatuan tujuan. Dengan demikian, setiap usaha dapat diarahkan pada tujuan yang sama. Akan tetapi, kesatuan tujuan ini tidak berarti bahwa harus selalu ada persetujuan/kesepakatan antara pihak manajemen dan karyawan, misalnya mengenai upah dan kondisi kerja.

10. Adanya Keterlibatan dan Pemberdayaan Karyawan

Agar dapat meningkatkan kemungkinan dihasilkannya keputusan yang baik, rencana yang baik, atau perbaikan yang lebih efektif, karena juga mencakup pandangan dan pemikiran dari pihak-pihak yang langsung berhubungan dengan situasi kerja serta meningkatkan 'rasa memiliki' dan tanggung jawab atas keputusan dengan melibatkan orang-orang yang harus melaksanakannya.

\section{Kinerja Manajerial}

Menurut Kornelius Harefa (2008 :17) pengertian kinerja manajerial adalah sebagai berikut "Kinerja manajerial adalah kemampuan atau prestasi kerja yang telah dicapai oleh para personil atau sekelompok orang dalam suatu organisasi, untuk melaksanakan fungsi, tugas dan tanggung jawab mereka dalam menjalankan operasional perusahaan.

Menjadi seorang manajer haruslah memiliki keahlian yang dapat menunjang pekerjaanya, Sri Wiludjeng SP dalam bukunya pengantar manajemen (2007: 6 ) mengemukakan beberapa keahlian (skill) yang harus dimiliki oleh seorang manajer, yaitu :

1. Technical skiil, yaitu kemampuan untuk menggunakan metode - metode, peralatan dan teknik - teknik dalam menjalankan suatu tugas.

2. Human skiil, yaitu kemampuan berkomunikasi, memaham dan memotivasi orang lain sehingga mereka dapat bekerja dengan baik.

3. Conceptual skiil, yaitu kemampuan inteligensia verbal dan kemampuan memandang sebuah organisasi sebagai satu sistem kesatuan.

4. Design skiil, yaitu kemampuan untuk memecahkan masalah dengan cara-cara yang menguntungkan perusahaan. 
Penilaian kinerja adalah penentuan secara periodik efektivitas operasional suatu organisasi, bagian organisasi dan karyawannya, berdasarkan sasaran, standar dan kriteria yang telah ditetapkan sebelumnya".

Oleh karena itu, pada dasarnya organisasi dioperasikan oleh sumber daya manusia, maka penilaian kinerja sesungguhnya merupakan penilaian atas perilaku manusia dalam melaksanakan peran yang mereka mainkan di dalam organisasi. Mulyadi (2000:419)

Hal ini seperti yang dikemukakan oleh Kurnianingsih dan Indriantoro (2003:24) dalam penelitiannya mengungkapkan dimensi untuk mengukur penilaian kinerja manajerial yang meliputi 8 (delapan) dimensi kegiatan sebagai berikut :

1. Kinerja Perencanaan (Planning)

Kinerja perencanaan yaitu kemampuan dalam penentuan kebijakan dan sekumpulan kegiatan untuk selanjutnya dilaksanakan dengan mempertimbangkan kondisi waktu sekarang dan yang akan datang. Perencanaan bertujuan untuk memberikan pedoman dan tata cara pelaksanaan tujuan, kebijakan, prosedur, penganggaran dan program kerja sehingga terlaksana sesuai dengan sasaran yang telah ditetapkan.

2. Kinerja Investigasi (Investigating)

Kinerja investigasi yaitu kemampuan dalam mengumpulkan dan menyampaikan informasi untuk catatan, laporan dan rekening, mengukur hasil, menentukan persediaan, serta analisis pekerjaan.

3. Kinerja Pengkoordinasian (Coordinating)

Kinerja pengkoordinasian yaitu kemampuan dalam tukar menukar informasi dengan orang di bagian organisasi lain untuk mengaitkan dan menyesuaikan program, memberitahukannya kepada bagian lain, dan hubungannya dengan manajer lain.

4. Kinerja Evaluasi (Evaluating)

Kinerja evaluasi yaitu kemampuan dalam menilai dan mengukur proposal, kinerja yang diamati atau dilaporkan yang meliputi penilaian pegawai, penilaian catatan hasil, penilaian laporan keuangan, dan pemeriksaan produk.

5. Kinerja Pengawasan (Monitoring)

Kinerja pengawasan yang dimaksud adalah kemampuan dalam memberikan pengarahan, memimpin dan mengembangkan bawahan, membimbing, melatih, dan menjelaskan peraturan kerja pada bawahan, menjelaskan tujuan kerja dan menangani keluhan pegawai.

6. Kinerja Pengaturan Staf (Staffing)

Kinerja pengaturan staf yang dimaksud adalah kemampuan untuk mempertahankan angkatan kerja yang ada pada bagian anda, melakukan perekrutan pegawai, mewawancarai mereka dan memilih pegawai baru, menempatkan pada bagian yang sesuai, mempromosikan dan memutasi pegawai.

7. Kinerja Negosiasi (Negotiating)

Kinerja negoisasi, yaitu kemampuan dalam melakukan pembelian, penjualan atau melakukan kontrak untuk barang dan jasa, menghubungi pemasok dan melakukan tawar menawar dengan penjual, serta tawar menawar secara kelompok.

8. Kinerja Perwakilan (Representating)

$41 \mid J u r n a l$ Manajemen \& Bisnis Kreatif 
Kinerja representasi yang dimaksud adalah kemampuan dalam menghadiri pertemuan-pertemuan dengan perusahaan lain, pertemuan dengan perkumpulan bisnis, pidato untuk acara-acara kemasyarakatan, pendekatan kemasyarakatan, serta kemampuan dalam mempromosikan tujuan utama perusahaan.

\section{Metode Penelitian}

Metode penelitian ini menggunakan pendekatan kuantitatif dengan menggunakan metode deskritif dan verifikatif dengan menggunakan metode analisa survei, dimana hasil survei berupa kuesioner akan digunakan untuk menganalisa bagaimana pengaruh variabel komitmen manajer $\left(\mathrm{X}_{1}\right)$ dan Implementasi Total Quality Management $(\mathrm{TQM})\left(\mathrm{X}_{2}\right)$ terhadap kinerja manajerial (Y). Disain penelitian yang digunakan adalah survey explanatory, yang menuntut penjabaran variabel-variabel penelitian ke dalam indikator-indikator yang dapat diukur secara kuantitatif sehingga dapat digunakan model uji hipotesis. Permasalahan yang akan diteliti berkaitan dengan pengaruh maka analisis yang digunakan adalah analisis regresi linier berganda, Analisis tersebut digunakan untuk menganalisis pengaruh komitmen manajer $\left(\mathrm{X}_{1}\right)$ dan Implementasi Total Quality Management (TQM) $\left(\mathrm{X}_{2}\right)$ terhadap kinerja manajerial (Y). Populasi dalam penelitian adalah Manajer utama / Manajer Quality Assurance pada perusahaan berbasis PMA Japan sudah memiliki sertifikat ISO dan terletak pada 5 kawasan di kawasan industri Karawang yaitu sebanyak 188 orang, sementara sampel sebesar 128 orang Manajer utama / Manajer Quality Assurance / Manajer produksi pada perusahaan berbasis PMA japan sudah memiliki sertifikat ISO dan terletak pada 5 kawasan di kawasan industri Karawang yaitu Kawasan Industri Mitra Karawang, Kawasan Industri International Industri City, Kawasan Industri Taisei, Kawasan Industri Surya Cipta Karawang Dan Kawasan Industri Kujang Cikampek,

\section{Teknik Pengambilan Sampel}

Teknik yang digunakan dalam pengambilan sampel dalam penelitian ini adalah probability sampling. Probability sampling adalah teknik pengambilan sampel yang memberikan peluang yang sama bagi setiap unsur (anggota) populasi yang dipilih menjadi sampel (Sugiyono, 2010:84). Sedangkan metode pengambilan sampling yang digunakan adalah stratified random sampling. Metode stratified random sampling dilakukan dengan memberikan kesempatan kepada anggota sampel yang sudah menjadi Manajer utama / Manajer Quality Assurance / Manajer produksi pada perusahaan di kawasan industri Karawang dengan cara memberikan kuisioner untuk diisi selama periode penelitian.

\section{Hasil Penelitian}

\section{Pengaruh Langsung dan Tidak Langsung}

Untuk mengetahui pengaruh Komitmen Manajer $\left(\mathrm{X}_{1}\right)$, Implementasi Total Quality Management (TQM) $\left(\mathrm{X}_{2}\right)$ terhadap Kinerja Manajerial (Y) dapat dilihat dikethaui melalui perhitungan analisi jalur (Path analisis).

Dari hasil pengolahan data dengan bantuan software SPSS 17, didapatkan koefisien jalur variabel Komitmen Manajer $\left(\mathrm{X}_{1}\right)$ dan Implementasi Total Quality 
Management (TQM) $\left(\mathrm{X}_{2}\right)$ terhadap Kinerja Manajerial $(\mathrm{Y})$, hasil tersebut dapat dilihat pada gambar dibawah ini :

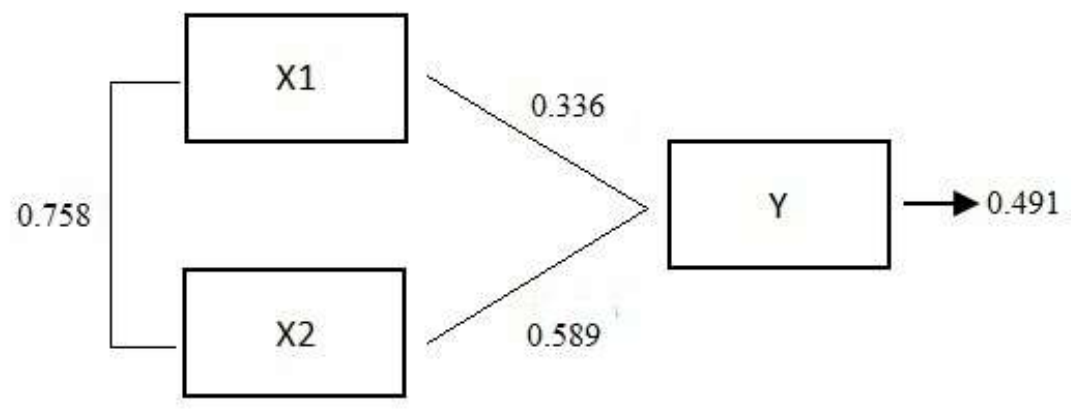

\section{Gambar 1}

Diagram Jalur (Path Analysis) X1 dan X2 terhadap Y

Dari diagram jalur diatas didapatkan hasil bahwa koefesien jalur Komitmen Manajer $\left(\mathrm{X}_{1}\right)$ terhadap terhadap Kinerja Manajerial $(\mathrm{Y})$ adalah sebesar 0.336, sementara koefesien jalur Implementasi Total Quality Management (TQM) $\left(\mathrm{X}_{2}\right)$ terhadap Kinerja Manajerial (Y) adalah sebesar 0.589, untuk koefisien jalur untuk faktor lain yang tidak masuk dalam spesifikasi adalah:

Pyع $=\sqrt{1-0.759}=0.491$

Dalam persentase, besarnya pengaruh dari variabel lain yang tidak diamati pada pengaruh komitmen Manajer $\left(\mathrm{X}_{1}\right)$ dan Implementasi Total Quality Management (TQM) $\left(\mathrm{X}_{2}\right)$ terhadap Kinerja Manajerial (Y) adalah sebesar 49.1\%. Selanjutnya untuk mengetahui pengaruh langsung dan tidak langsung Komitmen Manajer $\left(\mathrm{X}_{1}\right)$ dan Implementasi Total Quality Management (TQM) $\left(\mathrm{X}_{2}\right)$ terhadap Kinerja Manajerial (Y) dapat dilihat pada tabel dibawah ini :

Tabel 1

Pengaruh Langsung dan Tidak Langsung Komitmen Manajer $\left(\mathrm{X}_{1}\right)$ dan Implementasi Total Quality Management $(\mathrm{TQM})\left(\mathrm{X}_{2}\right)$ terhadap Kinerja Manajerial (Y)

\begin{tabular}{|c|c|c|c|}
\hline Variabel & Pengaruh Langsung & $\begin{array}{c}\text { Pengaruh Tidak } \\
\text { Langsung }\end{array}$ & Total \\
\hline $\begin{array}{c}\text { Komitmen } \\
\text { Manajer }\end{array}$ & $\begin{array}{c}0.336^{2}=0.112896 \mathrm{atau} \\
\text { atau } 11.29 \%\end{array}$ & $\begin{array}{c}0.336 \times 0.758 \times 0.589= \\
0.1500 \mathrm{atau} 15.00 \%\end{array}$ & $26.29 \%$ \\
\hline $\begin{array}{c}\text { Implementasi } \\
\text { TQM }\end{array}$ & $0.589^{2}=0.346921$ & $0.589 \times 0.758 \times 0.336=$ & $49.69 \%$ \\
atau $34.69 \%$ & $0.1500 \mathrm{atau} 15.00 \%$ & \\
\hline \multicolumn{3}{|c|}{ Total Pengaruh } & $\mathbf{7 5 . 9 8 \%}$ \\
\hline \multicolumn{3}{|c|}{ Pengaruh Variabel Lain $(\boldsymbol{\varepsilon})$} \\
\hline
\end{tabular}




\section{Sumber: hasil pengolahan data}

Dari tabel di atas dapat diketahui bahwa pengaruh langsung Komitmen Manajer $\left(\mathrm{X}_{1}\right)$ terhadap Kinerja Manajerial (Y) adalah sebesar $11.29 \%$, sedangkan pengaruh tidak langsung melalui Implementasi Total Quality Management (TQM) $\left(\mathrm{X}_{2}\right)$ adalah sebesar $15.00 \%$, sehingga total pengaruh Komitmen Manajer $\left(\mathrm{X}_{1}\right)$ terhadap Kinerja Manajerial (Y) secara keseluruhan sebesar 26.29\%.

Untuk pengaruh langsung Implementasi Total Quality Management (TQM) $\left(\mathrm{X}_{2}\right)$ terhadap Kinerja Manajerial (Y) didapatkan hasil sebesar 34.69\% sedangkan pengaruh tidak langsung melalui Komitmen Manajer $\left(\mathrm{X}_{1}\right)$ adalah sebesar 15.00\%, sehingga total pengaruh Implementasi Total Quality Management (TQM) $\left(\mathrm{X}_{2}\right)$ terhadap Kinerja Manajerial (Y) secara keseluruhan sebesar 49.69\%.

Dari hasil perhitungan diatas dapat diketahui bahwa Implementasi Total Quality Management (TQM) $\left(\mathrm{X}_{2}\right)$ memiliki pengaruh paling besar terhadap Kinerja Manajerial (Y) yaitu sebesar 49.69\%, sementara Komitmen Manajer ( $\left.\mathrm{X}_{1}\right)$ memiliki pengaruh paling kecil terhadap Kinerja Manajerial (Y) yaitu sebesar 26.29\%, sehingga total pengaruh secara keseluruhan Komitmen Manajer $\left(\mathrm{X}_{1}\right)$ dan Implementasi Total Quality Management $(\mathrm{TQM})\left(\mathrm{X}_{2}\right)$ terhadap Kinerja Manajerial (Y) adalah sebesar $75.98 \%$, sedangkan sisanya sebesar $(100 \%-75.98 \%=24.02 \%)$ dipengaruhi opleh faktor lain diluar penelitian ini.

Faktor lain diluar penelitian yang dapat mempengaruhi kinerja manajerial pada perusahaan-perusahaan di 5 kawasan industri karawarang merupakan faktor pengawasan, pengawasan tersebut berguna sebagai alat yang digunakan untuk mengendalikan dan memonitor serta mengevaluasi terhadap kinerja manajerial perusahaan yang telah dilakukan dengan membandingkannya dengan program kerja yang telah dibuat. Selain itu faktor pengawasan anggaran tinggi (rendah) dengan ketidakpastian lingkungan rendah (tinggi) dapat menimalisasi job related tension sehingga dapat berdampak pada kinerja manajerial.

\section{Pembahasan Penelitian} Pembahasan Deskriptif

Berdasarkan hasil analisis yang dikaitkan dengan fenomena-fenomena, maka dapat sampaikan sebagai berikut :

1. Tanggapan responden pada Komitmen manager $\left(\mathrm{X}_{1}\right)$ memiliki skor sebesar 547.6 yang berada pada rentang 537.5-664.0 dengan kriteria tinggi, yang dapat diartikan bahwa komitmen manager pada perusahaan di 5 kawasan industri Karawang sudah sesuai dengan yang diharapkan dilihat dari Komponen Afektif, Komponen Normatif dan Komponen Continuence, namun terdapat tanggapan kurang positif pada komponen afektif yaitu adanya perbedaan persepsi serta keinginan dari manager perusahaan dengan menejerial perusahaan dalam hal program kerja perusahaan, hal tersebut menyebabkan rendahnya keinginan manager untuk bergabung dengan perusahaan, menjalankan program perusahaan yang menurunkan komitmen terhadap perusahaan, komponen normatif yaitu sikap ketidakpuasan menager terhadap manajemen perusahaan dikarenakan adanya perbedaan persepsi serta ketidakpuasaan terhadap 
kompensasi yang diterima, kurangnya pengelolaan menejemen perusahaan terhadap kinerja SDM nya dan kurangnya motivasi dari para manager untuk dapat mengembangkan pengetahuannya serta kurang mendukungnya lingkungan kerja diperusahaan dan terakhir pada komponen Continuenc yaitu usaha yang dilakukan oleh manager belum semaksimal mungkin terhadap perusahaan karena lingkungan fisik kerja, rendahnya kesemaptaan berkembang diperusahaan dan beban kerja yang terlalu berat yang menyebabkan kurang maksimalnya kerja yang dilakukan oleh manager.

2. Tanggapan responden pada Implementasi Total Quality Management (TQM) $\left(\mathrm{X}_{2}\right)$ memiliki skor sebesar 562.5 yang berada pada rentang 537.5-664.0 dengan kriteria baik, yang dapat diartikan bahwa komitmen manager pada perusahaan di 5 kawasan industri Karawang sudah sesuai dengan yang diharapkan dilihat dari Fokus pada pelanggan, Obsesi terhadap kualitas, Pendekatan Ilmiah, Komitmen jangka panjang, Kerjasama (Team work), Perbaikan sistem secara berkesinambungan, Pendidikan dan pelatihan, Kebebasan yang terkendali, Kesatuan tujuan dan Adanya Keterlibatan dan pemberdayaan karyawan, namun terdapat tanggapan kurang positif pada namun terdapat tanggapan kurang positif pada fokus pada pelanggan yang disebabkan karena perusahaan belum sepenuhnya dapat memenuhi harapan dari para pelanggannya, pada komponen perbaikan sistem secara berkesinambungan karena sistem teknologi yang dimiliki oleh perusahaan kurang memadai serta kegagalan strategi manajemen perusahaan untuk dapat meningkatkan kualitas perusahaan melalui kinerja para karyawannya, pada komponen kebebasan yang terkendali yang disebakan karena masih kurangnya pengikutsertaan para karyawan diperusahaan terhadap pengambilan keputusan dan pada komponen kesatuan tujuan disebabkan karena adanya persaingan yang tidak sehat antara tim, mengakibatkan kerja sama yang belum dapat menghasilkan kinerja yang optimal.

3. Tanggapan responden pada Kinerja Manejerial (Y) memiliki skor sebesar 598.4 yang berada pada rentang 537.5-664.0 dengan kriteria puas, yang dapat diartikan bahwa kinerja manajerial pada perusahaan di 5 kawasan industri Karawang sudah memuaskan dilihat dari KinerjaPerencanaan (Planning), Kinerja Investigasi (Investigating), KinerjaPengkoordinasian (Coordinating), Kinerja Evaluasi (Evaluating), Kinerja Pengawasan (Monitoring), Kinerja Pengaturan Staf (Staffing), Kinerja Negosiasi (Negotiating) dan Kinerja Perwakilan (Representating), namun terdapat tanggapan kurang positif pada Kinerja Perencanaan (Planning) yaitu yang disebabkan karena masih kurang jelasnya tujuan program kerja yang telah dibuat oleh management perusahaan bagi para karyawan serta Kinerja Pengaturan Staf (Staffing) yang disebabkan karena masih terbatasnya tenaga kerja yang berkualitas serta karena kesalahan manajemen perusahaan dalam menempatkan karyawan sesuai dengan keahlian yang dimiliki.

\section{Pembahasan Verifikatif}

Berdasarkan hasil penelitian yang telah diuraikan sebelumnya, maka dapat disampaikan mengenai pembahasan verifikatif berikut ini: 
1. Koefesien jalur variabel Komitmen Manajer $\left(\mathrm{X}_{1}\right)$ terhadap Kinerja Manajerial (Y) adalah sebesar 0.336 , berdasarkan hasil pengujian hipotesis secara parsial diperoleh nilai sig $(0.000)<\alpha(0.05)$ dan nilai $\mathrm{T}_{\text {hitung }}(5.554)>\mathrm{T}_{\text {tabel }}(1.975)$ maka Ho ditolak, dengan demikian dapat disimpulkan terdapat pengaruh yang signifikan secara parsial antara Komitmen Manajer $\left(\mathrm{X}_{1}\right)$ terhadap Kinerja Manajerial (Y).

2. Koefesien jalur variabel Implementasi Total Quality Management (TQM) $\left(\mathrm{X}_{2}\right)$ terhadap Kinerja Manajerial (Y) adalah sebesar 0.589, berdasarkan hasil pengujian hipotesis secara parsial diperoleh nilai sig $(0.000)<\alpha(0.05)$ dan nilai $\mathrm{T}_{\text {hitung }}(9.751)>\mathrm{T}_{\text {tabel}}(1.975)$ maka Ho ditolak, dengan demikian dapat disimpulkan terdapat pengaruh yang signifikan secara parsial antara Implementasi Total Quality Management (TQM) $\left(\mathrm{X}_{2}\right)$ terhadap Kinerja Manajerial (Y).

3. Pengaruh langsung variabel Komitmen Manajer $\left(X_{1}\right)$ terhadap Kinerja Manajerial (Y) adalah sebesar $11.29 \%$, sementara pengaruh tidak langsung melalui Implementasi Total Quality Management (TQM) $\left(\mathrm{X}_{2}\right)$ adalah sebesar $15.00 \%$, sehingga total pengaruh Komitmen Manajer $\left(\mathrm{X}_{1}\right)$ terhadap Kinerja Manajerial (Y) adalah sebesar 26.29\%.

4. Pengaruh langsung variabel Implementasi Total Quality Management (TQM) $\left(\mathrm{X}_{2}\right)$ terhadap Kinerja Manajerial $(\mathrm{Y})$ adalah sebesar $34.69 \%$, sementara pengaruh tidak langsung melalui Komitmen Manajer $\left(\mathrm{X}_{1}\right)$ adalah sebesar $15.00 \%$, sehingga total pengaruh Implementasi Total Quality Management $(\mathrm{TQM})\left(\mathrm{X}_{2}\right)$ terhadap Kinerja Manajerial $(\mathrm{Y})$ adalah sebesar $49.69 \%$, sehingga total pengaruh secara keseluruhan variabel Komitmen Manajer $\left(\mathrm{X}_{1}\right)$ dan Implementasi Total Quality Management (TQM) $\left(\mathrm{X}_{2}\right)$ terhadap Kinerja Manajerial (Y) adalah sebesar $75.98 \%$, sementara pengaruh variabel lainnya sebesar $49.1 \%$, berdasarkan hasil pengujian hipotesis secara simultan didapatkan nilai $\operatorname{sig}(0.000)<\alpha(0.05)$ dan nilai $F_{\text {hitung }}(244.538)>F_{\text {tabel }}(3.054)$ maka Ho ditolak, dengan demikian dapat disimpulkan terdapat pengaruh yang signifikan antara Komitmen Manajer $\left(\mathrm{X}_{1}\right)$ dan Implementasi Total Quality Management (TQM) $\left(\mathrm{X}_{2}\right)$ terhadap Kinerja Manajerial (Y).

\section{Kesimpulan}

Berdasarkan hasil penelitian maka dapat disimpulkan sebagai berikut :

1. Komitmen manajer di perusahaan-perusahaan di kawasan industri Karawang berada pada kategori tinggi, hal ini disebabkan karena responden menganggap bahwa komitmen yang dimiliki oleh manager dapat mendorong keberhasilan penerapan kualitas kerja di perusahaan serta adanya kepuasan kerja dari karyawan terhadap para manajer, tetapi masih ada dimensi yang menunjukan kriteria kurang baik / tinggi yaitu pada dimensi komponen afektif. yaitu pada indikator keinginan manager untuk bergabung dengan perusahaan disebabkan adanya perbedaan persepsi serta keinginan dari manager perusahaan dengan menejerial perusahaan dalam hal program kerja perusahaan, hal tersebut menyebabkan rendahnya keinginan manager untuk bergabung dengan perusahaan, menjalankan program perusahaan yang dapt menurunkan komitmen manager terhadap perusahaan, pada komponen normatif adanya sikap 
E-ISSN: 2580-5428

ketidakpuasan manager terhadap manajemen perusahaan dikarenakan adanya perbedaan persepsi serta ketidakpuasaan terhadap kompensasi yang diteriman sehingga mengakibatkan turunnya komitmen manager serta komponen continuence pada indikator adanya usaha dari manager sesuai dengan tujuan perusahaan, yang disebakankan usaha yang dilakukan oleh manager belum semaksimal mungkin dan pada indikator manager dapat memaksimalkan setiap kerjanya diperusahaan, yang disebakan karena lingkungan fisik kerja, serta rendahnya kesempatan berkembang diperusahaan dan beban kerja yang terlalu berat.

2. Implementasi Total Quality Management (TQM) di perusahaan-perusahaan di kawasan industri Karawang berada pada kategori baik, hal ini disebabkan karena responden menganggap bahwa sistem manajemen diperusahaan telah berhasil mengangkat kualitas sebagai strategi usaha dan berorientasi pada kepuasan konsumen dengan melibatkan seluruh anggota perusahaan, tetapi masih ada dimensi yang menunjukan kriteria kurang baik yaitu pada dimensi Fokus pada pelanggan, Perbaikan system secara berkesinambungan, kebebasan yang terkendali dan kesatuan tujuan, hal ini disebabkan karena terdapat beberapa produk perusahaan yang belum sesuai dengan harapan para pelanggan dan juga disebabkan karena sistem teknologi yang dimiliki oleh perusahaan, kurang memadai, terdapat permasalahan-permasalahan yang timbul yang berasal dari sistem yang lama kegagalan strategi manajemen perusahaan untuk dapat meningkatkan kualitas perusahaan melalui kinerja para karyawannya dan adanya persaingan yang tidak sehat di dalam perusahaan sehingga menghasilkan kinerja yang optimal.

3. Kinerja Manejerial di perusahaan-perusahaan di kawasan industri Karawang berada pada kategori puas, hal ini disebabkan karena karyawan selalu diberikan kesempatan oleh menejerial perusahaan untuk mengajukan pendapat pada proses penyusunan program yang bersifat partisipasi, tetapi masih ada dimensi yang menunjukan kriteria kurang baik yaitu pada dimensi Kinerja Perencanaan (Planning), Kinerja Pengaturan Staf (Staffing). Hal ini disebabkan karena masih kurang jelasnya tujuan program kerja yang telah dibuat oleh management perusahaan bagi para karyawan. dan yang disebabkan karena masih terbatasnya tenaga kerja yang berkualitas. dan juga karena kesalahan manajemen perusahaan dalam menempatkan karyawan sesuai dengan keahlian yang dimilki.

4. Besarnya pengaruh Komitmen manajer terhadap Kinerja manajerial di perusahaan-perusahaan di kawasan industri Karawang adalah sebesar 0.336

5. Besarnya pengaruh Implementasi Total Quality Management (TQM) terhadap Kinerja manajerial di perusahaan-perusahaan di kawasan industri Karawang adalah sebesar 0.589 .

6. Besarnya pengaruh Komitmen manajer dan Implementasi Total Quality Management (TQM) terhadap Kinerja manajerial di perusahaan-perusahaan di kawasan industri Karawang adalah sebesar 0.758.

\section{Saran}

Saran-saran yang dapat bermanfaat secara praktis adalah : 
1. Berdasarkan hasil tanggapan didapatkan hasil bahwa komitmen manager memperoleh tanggapan paling terkecil, hal ini dapat diartikan bahwa responden menganggapan bahwa komitmen yang dimiliki manajer-manajer pada perusahaan belum sepenuhnya dijalankan, hal tersebut dikarenakan masing adanya ketidakpuasan dari manager terhadap perusahaan, komitmen manager terhadap perusahaan masih rendah sehingga menger belum dapat memberikan yang terbaik bagi perusahaan, faktor adanya kompensasi menjadi salah satu penyebab yang dapat menurunkan komitmen manager pada perusahaan yang ia pimpin.

2. Dengan mengetahui karakteristik konsumen yang datang, pihak managemen perusahaan tentunya akan lebih mudah untuk malayani dan memuaskan kebutuhan konsumenya, pihak menejemen sebaiknya mengadakan program promosi untuk menjaring lebih banyak konsumen serta perlunya peningkatan sistem agar kualitas produk perusahaan dapat terjaga dan lebih meningkat.

Perlunya perusahaan-perusahaan dikawasan industri Karawang meningkatkan kinerja serta kemampuan manajer dalam melaksanakan tanggungjawabnya terhadap kualitas produk, kuantitas produk, ketepatwaktuan produk, pengembangan produk baru, pengembangan personel, pencapaian anggaran, pengurangan biaya (peningkatan pendapatan) dan urusan publik.

\section{Daftar Pustaka}

Achmad Kuncoro, Engkos dan Ridwan, 2008, “ Análisis jalur (Path Análisis), Edisi kedua, Penerbit Alfabeta, Bandung.

A.A. Anwar Prabu Mangkunegara, 2007, Manajemen Sumber Daya Manusia, Cetakan Ke Tujuh PT. Remaja Rosdakarya, Bandung.

Brah, A. Shaukat and Lim, Ying Hua. 2006. The effects of technology and TQM on theperformance of logistics companies. International Journal of Physical Distribution \&Logistics Management 36(3):192-209.

Bhat, V. and J. Cozzolino. 1993. Total Quality: An Effective Management Tool. www.casact.org.pp.101-123. Agustus 2005

Feigenbaum, A.V. 2000. Kendali Mutu Terpadu, Jilid 1, Edisi Ketiga, Erlangga, Jakarta

Goetsch, David. L, Staanley B.Davis, 2002, Quality Management, Introduction to Total Quality Management for Production, processing, and services, New Jersey: Prentice Hall

Jay Heizer dan Barry Render. 2004 Operation Management, 7th edition. (Manajemen Operasi edisi 7, Buku 1 ) Penerbit Salemba Empat. Jakarta.

Kotler, P. 2005. Manajemen Pemasaran. Edisi 11, Jilid 1. Gramedia Pustaka Utama, Jakarta.

Kotler Philip dan Amstrong, 2001, Prinsip-Prinsip Manajemen, Jilid 1 Edisi Kedelapan, Alih Bahasa Oleh Damos Sihombing, MBA., Penerbit Erlangga, Jakarta.

Kurnianingsih, R. 2003. "Pengaruh Sistem Pengukuran Kinerja dan Sistem Penghargaan terhadap Keefektifan Penerapan Tekhnik Total Quality Manajemen: Studi Empiris Pada Perusahaan Manufactur di Indonesia,"

$48 \mid J u r n a l$ Manajemen \& Bisnis Kreatif 
E-ISSN: 2580-5428

Mutiara, S. Panggabean, 2004, Manajemen Sumber Daya Manusia, Bogor: Ghalia Indonesia.

Nasution,M. 2005, “Total Quality Management”, PT Gramedia Pustaka Utama: Jakarta

Nasution, 2007.Metode Research: Penelitian Ilmiah.Jakarta: Bumi Aksara.

Panggabean, Mutiara Sibarani, 2004, Manajemen Sumber Daya Manusia, Jakarta: Ghalia Indonesia

Riduwan dan Sunarto. 2007. Pengantar Statistika. Bandung: CV Alfabeta

Schein, Edgar H. 2008, Organizational Culture and Leadership, 3rd edition, San Fransisco: Jossey-Bass.

Sunarto. 2005. Manajemen Karyawan. Yogyakarta: AMUS Yogyakarta \& Aditya Media Yogyakarta

Sutrisno, Edy. 2012. Manajemen Sumber Daya Manusia. Jakarta : Kencana Prenada Media.

Sunarto. 2005. Manajemen Karyawan. Yogyakarta: AMUS Yogyakarta \& Aditya Media Yogyakarta

Sugiyono, 2008, “Metode Penelitian Administrasi”, CV Alfabeta: Bandung

Sugiyono, 2009, "Metode Penelitian Kuantitatif Kualitatif dan R\&D”, CV Alfabeta: Bandung

Tjiptono, Fandy dan Gregorius Chandra. 2005. Service, Quality dan Satisfaction. Yogyakarta : Andi.

Terry, George R. dan Rue, Leslie W. 2005. Dasar-Dasar Manajemen. Jakarta : Bumi Aksara

Ticoalu). Jakarta: Bumi Aksara 2010. Dasar-dasar Manajemen. (Terje: G.A.

Terry, George R \& Rue, Leslie W. Rue. 2010. Dasar-dasar Manajemen. (Terje: G.A. Ticoalu). Jakarta: Bumi Aksara.

Utami Munandar. 2004. Pengembangan Kreativitas Siswa Berbakat. Jakarta :Rineka Cipta

Wiludjeng, Sri SP,2007. Pengantar Manajemen, Yogyakarta: Graha Ilmu. 